\title{
ANIONAKTÍV DETERGENS TARTALOM MEGHATÁROZÁSA SZÜRKEVIZEKBEN
}

\section{DETERMINATION OF ANIONIC DETERGENT CONTENT IN GREYWATER}

\author{
Lós Réka ${ }^{1}$, Izbékiné Szabolcsik Andrea², Bodnár Ildikó ${ }^{3}$ \\ 1,2,3,Debreceni Egyetem, Müszaki Kar, Környezetmérnöki Tanszék \\ Cím: 4028 Magyarország, Debrecen, Ótemető utca, 2-4; \\ ${ }^{1}$ losrekaaa@gmail.com² szabolcsikandi@eng.unideb.hu ${ }^{3}$ bodnari@eng.unideb.hu
}

\begin{abstract}
In our research we improved a method for the determination of anionic detergent content (ANA) of greywater samples. Based on the earlier studies at the Environmental Engineering Department of University of Debrecen this new, more reliable method for ANA values is very effective. We examined the quantity of anionic detergent content in synthetic greywater samples with Hyamine reagent using two-phased titrimetric method. We added to the synthetic greywater samples phenolphthalein indicator, acid mixed indicator and chloroform. After we shaked the mixture, and we got two separated phase. We titrated the mixture with cation active Hyamine reagent. It was shown that the applied method is representative and reliable, too.
\end{abstract}

Keywords: anionic detergent, greywater, two-phased titration.

\section{Összefoglalás}

Kutatásunk célja a szürkevizek anionaktív detergens tartalmának meghatározására alkalmas módszer fejlesztése. A Debreceni Egyetem Környezetmérnöki Tanszékén korábban folyó anionaktív detergens tartalom meghatározására vonatkozó kutatások nem bizonyultak megbízhatónak, ezért újabb, megbízhatóbb módszert dolgoztunk ki. Laboratóriumi körülmények között előállított szintetikus szürkevíz anionaktív detergens tartalmát határoztuk meg Hyamine reagenssel, kétfázisú titrimetriás módszerrel. Adott mennyiségű szintetikus szürkevíz mintához fenolftalein indikátort, savas keverék indikátort és kloroformot adtunk, majd az elegy összerázás hatására két fázisra vált szét, kloroformos és vizes fázisra. Az elegyet kationaktív detergenst tartalmazó Hyamine reagenssel titráltuk. Vizsgálataink során az anionaktív detergens tartalom meghatározása illetve a módszerfejlesztés reprezentatívnak és megbízhatónak bizonyult.

Kulcsszavak: anionaktív detergens, szürkevíz, kétfázisú titrálás.

\section{Bevezetés}

A Föld édesvíz készlete a rohamos népességnövekedés és a növekvő igények hatására egyre csökken. Ezért szükséges minél hamarabb olyan lehetöségek után kutatni, amivel mérsékelhetjük [1], illetve szabályozhatjuk a vízfogyasztásunkat. Egy lehetséges módszernek bizonyul víztakarékosság szempontjából, ha a háztartásokban például WC-öblítésre, öntözésre vagy autómosásra úgynevezett szürkevizet használunk. 


\section{Szürkevizek fogalma}

Szürkevizeknek tekinthetők a háztartásokban mosás, mosogatás, kézmosás, fürdés során keletkező vizek, melyekhez nem tartoznak a vízöblítéses WC-k vizei [1]. A szürkevizek nagy mennyiségű felületaktív anyagot, ún. detergenst is tartalmazhatnak, amit felhasználás vagy vízbázisokba történő kijuttatás előtt szükségszerủ eltávolítani. A különböző típusú szürkevizekben található detergens tartalom a háztartásban használt koz-metikumokból, samponból, tusfürdőböl, mosó- és mosogatószerekből stb. származik. Ghaitidak és munkatársai [1] megállapításai szerint a fürdésből, tisztálkodásból származó szennyvizek 15-60 mg/l mennyiségben, a mosásból származó szürkevizek akár $120 \mathrm{mg} / \mathrm{l}$ és a mosogatás során keletkező szennyvizek 40-50 mg/l koncentrációban tartalmazhatnak anionaktív detergenst (röviden ANA-detergens). A háztartásokban keletkező szürkevizek minősége nagymértékben függ a ház-tartásban élők számától, koreloszlatástól, higiéniai szokásától és a földrajzi helyzettől is [1]. A Környezetmérnöki Tanszéken évek óta folyó kutatások során adekvát mérésekkel is sikerült bebizonyítani, hogy a szürkevizek minősége nagyon változó [2]. Kutatásunk célja a szürkevizekböl ezen felületaktív anyagok meghatározására alkalmas módszer fejlesztése, a későbbi kezelési megoldások ellenőrzésére az ún. ANA-tartalom pontos ismerete a témában elengedhetetlen.

\section{Detergensek meghatározása}

Napjainkban számos területen használnak felületaktív anyagokat, ezek az anyagok a kémiai vegyületek azon csoportját képzik, melyeket széles körben alkalmaznak az iparban, a kozmetikai termékekben, háztartási termékekben, illetve egyéb más területeken, mivel képesek csökkenteni az oldószerek felületi feszültségét [3,4]. A detergenseket kémiai szerkezetük szerint 4 csoportba sorolhatjuk, anionaktív-, kationaktív-, nemionos és amfoter detergenseket különböztetünk meg [5,6]. Használat után a detergensek és termékeik a kommunális szennyvizekkel a szennyvíztisztító telepekre kerülnek, majd kijuthatnak a felszíni vizekbe és az iszapok ártalmatlanításán keresztül a környezetben diszpergálódnak. A detergensek antropogén eredetủ környezetbe jutása káros lehet, mivel meggátolja az oxigén diffúzióját a vizekben, továbbá magas szulfáttartalom esetén algavirágzást okozhat. Zavarják a szennyvíztisztítást, az ivóvíztisztítást, rontják a felszíni vizek öntisztulásának a hatásfokát [7,8].

\subsection{Anionaktív detergensek meg- határozásának lehetőségei}

A detergens tartalom meghatározására több nemzetközi ajánlás is ismeretes (titrimetriás, elektroanalitikai, fotometriás), melyek változatos módszertannal végzik ezen alkotók összes mennyiségének azonosítását [3].

A Debreceni Egyetem Müszaki Karának egyik kutatócsoportja korábbi kutatásuk során vizsgálta a szürkevizek anionaktív detergens tartalmát az MSZ 448-49: 1981es számú Magyar Szabvány alapján. A szabvány szerint detergensek metilénkék indikátorral savas közegben kékszínü komplex vegyületet képeznek és oldódnak kloroformban. Így kinyerhetők extrakcióval, mert a metilénkék kloroformban oldhatatlan marad. A nyert extraktum színerőssége $2 \mathrm{mg} / \mathrm{l}$ koncentrációig arányos a benne lévő anionaktív detergens koncentrációjával. A módszer kapcsán a mintákat hígították, hogy a detergens tartalmuk 0,4 és 2,0 mg/l koncentráció tartományba essen. Az ANA-detergensek mennyiségi meghatározását zavarhatja a szürkevizek szervesanyag tartalma (>25 mg/l) és nitrát koncentrációja (>350 mg/l). A vizsgált szürkevíz mintákban az esetleges zavaró hatásokat sikerült a minták hígításával kiküszöbölniük. Viszont nem minden fürdöés mosogatóvíz minta esetén tudtak kimuta- 
tási határ felett mérni, a hígítás miatt [9]. Ebből is látható, hogy az MSZ 448-49: 1981-es számú Magyar Szabvány szerint végzett mérés igen körülményes, lassú és nagy vegyszer- és eszközigényü, illetve egyes esetekben nem megbízható eredményt ad.

A módszerfejlesztési törekvéseinket nagymértékben segítette, hogy a Tanszéken folyó korábbi kutatások alkalmával kidolgoztak egy szintetikus szürkevizet, mely jól reprezentálja a régióban keletkező átlagos fürdővíz mintákat. Az így fejlesztett állandó összetételü szintetikus szürkevízzel többek között a detergens tartalom meghatározására szolgáló módszer-fejlesz-tési kísérleteink eredményei is jól össze-hasonlíthatók egymással.

Kutatásunk célja az volt, hogy olyan esetlegesen egyedi módszert dolgozzunk ki, mellyel a szürkevizek detergens tartalma gyorsabban, pontosabban és kevésbé környezetszennyező eljárással mérhető legyen egyszerü titrimetriás vizsgálat segítségével. Kísérleteinkben egy ún. kétfázisú titrimetriás [10] módszert alkalmaztunk, mely az ISO 2271:1989 szabvány alapján történik. A szabványos körülmények a következők: meghatározott mennyiségü mintát zárható jódszám lombikban titráltunk. A vizsgált minta $\mathrm{pH}$-ját fenolftalein indikátorral beállítottuk, amit a halvány-rózsaszín szín megjelenése vagy eltünése jelzett. Ezt követően $5 \mathrm{ml}$ ún. savas keverék indikátort (dimidium bromid - diszulfin kék) adtunk a lombikba, végül pedig $5 \mathrm{ml}$ kloroformot. A jódszám lombikot ezt követően lezártuk és erősen rázogattuk. A rázogatás hatására két fázist kaptunk, egy felső vizes fázist, illetve egy alsó kloroformos fázist, amely az indikátor hatása miatt rózsaszín. Ezután a jódszámlombikban található elegyet 0,004 $\mathrm{mol} / \mathrm{dm}^{3}$ koncentrációjú Hyamine reagenssel (benzetónium-klorid) titráltuk. A mérőoldat adagolását addig végeztük, míg a lombikban található alsó kloroformos rész halványkék színü nem lett. A módszer alap- ján, ha zöldeskék színt tapasztalunk, azt jelzi, hogy az oldatot túltitráltuk.

\section{Kutatás eredménye}

A módszerfejlesztésünk alkalmával először is a szintetikus szürkevíz mintában a nemzetközi szabványban leírt módszerrel meghatároztuk az ANA-detergens tartalmat (lásd 3.1. fejezet), mely alkalmával a párhuzamos mérések között szignifikáns különbséget tapasztaltunk. 50, 100 és $200 \mathrm{~cm}^{3}$ térfogatú szürkevíz minta vizsgálata során ANA-detergens tartalomra a következő értékeket kaptuk: $50 \mathrm{~cm}^{3}$ mintában átlag $71,69 \mathrm{mg} / \mathrm{l}, 100 \mathrm{~cm}^{3}$ mintában 62,73 mg/l és $200 \mathrm{~cm}^{3}$ mintában pedig 58,25 mg/l. A várttól eltérően a detergens tartalom ugyanazon szintetikus fürdővíz minta esetében a mintatérfogat növelésével csökkent, mely a módszer instabilitására utal. A következő lépésben emeltük a mintatérfogatokhoz adagolt kloroform mennyiségét. $100 \mathrm{~cm}^{3}$ mintához $10 \mathrm{ml}$, míg $200 \mathrm{~cm}^{3}$ mintához 20 ml kloroformot adtunk. Ebben az esetben mind a két vizsgálat során az ANAdetergens tartalom 58,25 mg/l-nek adódott. Ezáltal a kloroform mennyiségének emelésével a módszer reprodukálhatóságát biztosítani tudtuk. Az alapmódszer stabilitását bizonyítva, a következőkben vizsgáltuk, hogy különböző szintetikus szürkevíz öszszetételek hogyan befolyásolják az ANAdetergens tartalmat. Ezért 3 különböző szintetikus szürkevíz mintát készítettünk el. Az első minta a receptben megadott összetevőket tartal-mazta, míg a második minta ezen összetevők fele akkora mennyiségét, a harmadik minta pedig az alap receptben leírt mennyiségek kétszeresét. A vizsgálat során kapott értékek igazolták a módszer megbízhatóságát. Az ANA-detergensek mennyisége 53,77 mg/l adódott a normál szintetikus fürdővíz mintában, míg a fele mennyiségü összetevőt tartalmazó szin-tetikus fürdővízben fele mennyiségü ANA-detergens tartalmat $(26,88 \mathrm{mg} / \mathrm{l})$ kaptunk. A kétszeres 
mennyiségü összetevőt tartalmazó szintetikus fürdővízben kétszer annyi ANAdetergens tartalmat $(106,50 \mathrm{mg} / \mathrm{l})$ detektáltunk.

A következőkben a szintetikus szürkevizet hígabb, $0,002 \mathrm{~mol} / \mathrm{dm}^{3}$-es Hyaminenal titráltuk. Azt tapasztaltuk, hogy a méröoldat koncentrációjával arányosan változik a fogyás adat és a mért ANA-detergens érték. Alacsonyabb detergens tartalmak meghatározásánál a hígabb oldattal végezett mérés magasabb fogyásértékei könnyebben követhetőek. Ez a kísérlet hasznosnak bizonyult a módszer megbízhatóságának vizsgálata kapcsán, mivel bebizonyosodott, hogy az $50 \mathrm{~cm}^{3}$ vízmintát $0,002 \mathrm{~mol} / \mathrm{dm}^{3}$-es Hyamine-nal titrálva ugyanazt az eredményt kaptuk, mint amikor $100 \mathrm{~cm}^{3}$ vízmintát titráltunk $0,004 \mathrm{~mol} / \mathrm{dm}^{3}$-es Hyamine-nal, amely 51,98 mg/l.

\section{Következtetések}

A korábbi kutatási eredményekkel ellentétben a kétfázisú titrálás egy nagyon egyszerủ és gyors meghatározási módszer, viszonylag kevés eszköz- és vegyszerszükséglettel és nem utolsó sorban olcsó meghatározási eljárásnak bizonyult.

Javasolt a szabvány szerint elöírt $5 \mathrm{ml}$ kloroform mennyiségének megduplázása, mert biztosabban észlelhető a színváltozás és a végpont. A különböző vízminták vizsgálata során megállapítható, hogy a recept szerinti fele és kétszeres mennyiségü anionos detergenst tartalmazó vízminta ANAdetergens értéke ténylegesen fele illetve kétszeres, mely igazolja a módszer megbízhatóságát szürkevizek elemzésében. Alacsony anionaktív detergens tartalmú minták esetén hasznos lehet, a mérőoldat koncentrációját $0,002 \mathrm{~mol} / \mathrm{dm}^{3}$-re csökken-teni, és kisebb mintatérfogattal titrálni.

\section{Köszönetnyilvánítás}

A publikáció elkészítését az EFOP3.6.1-16-2016-00022 számú projekt támogatta. A projekt az Európai Unió támogatá- sával, az Európai Szociális Alap társfinanszírozásával valósult meg.

\section{Szakirodalmi hivatkozások}

[1] Ghaitidak, D. M., \& Yadav, K. D. (2013). Characteristics and treatment of greywaterA review. Environmental Science and Pollution Research, 20(5), 2795-2809. [Hozzáférés dátuma: 04. 08. 2017.].

[2] Bodnar, I., Szabolcsik, A., Baranyai, E., Uveges, A., Boros, N. (2014). Qualitative Characterization of the Household Greywater in Northern Great Plain Region of Hungary. Environmental Engineering and Management Journal, Vol. 13, N.11 27172724.

[3] M. Toledo: Good Titriation Practice in surfactant titriation. https:/www.mt.com/dam/labdiv/campaigns/g p/gtp/gtp_surfactant.pdf [21.09.2017.]

[4] Galović, O., Samardžić, M., Petrušić, S., \& Sak-Bosnar, M.: A new sensing material for the potentiometric determination of anionic surfactants in commercial products. Int. J. Electrochem. Sci, 9, 2014, 3802-3818. [09.11.2017.]

[5] Juhász, É., \& Erős, M. L.I: (1979). Felületaktív anyagok zsebkönyve. Müszaki Könyvkiadó. 398. oldal (15. o.) ISBN: 96310 24709 [06.09.2017.]

[6] Barótfi, I.: Szolgáltatástechnika [Service technology]. Mezőgazda Kiadó, Budapest 2001. p. 13-25, 153-161 [09.11.2017.]

[7] Ying, G. G.: (2006). Fate, behavior and effects of surfactants and their degradation products in the environment. Environment international, 32(3), 417-431. [11.11.2017.].

[8] L. Sujbert: Tenzid xenobiotikumok az emberi környezetben, kölcsönhatásaik a humán ökoszisztémával [12.11.2017.].

[9] G. Jolánkai, N. Boros, A. Keczánné Üveges. S. Fórián, D. Kocsis, E. Fehérné Baranyai, A. Izbékiné Szabolcsik, I. Bodnár, Kalmár Ferenc: Fenntartható energetika megújuló energiaforrások optimalizált integrálásával. Akadémiai Kiadó, Budapest, 2014, 403 oldal ISBN: 978-963-05-9540-7 [14.07.2017.].

[10] Cullum, D. C. (Ed.). (1994). Introduction to surfactant analysis. London: Blackie Academic \& Professional. [Hozzáférés dátuma: 13. 11. 2017.] 